\title{
Applicability of Model Assessment for Learning (AFL) in Classes of Vocabulary and Pragmatics in English Teaching Learning at STAIN Salatiga
}

\author{
Woro Retnaningsih \\ IAIN Surakarta \\ Jl. Pandawa Pucangan Kartasura, \\ Sukoharjo, Central Java, Indonesia \\ woro_solo@yahoo.com
}

\begin{abstract}
The research objective is to see the applicability of Assessment for Learning (AFL) in the classes of vocabulary and pragmatics. The subjects of the research were students and lecturers of Vocabulary 3 and Pragmatics classes. The research was conducted in State Islamic Studies Institute (STAIN) Salatiga, Central Java, Indonesia. The results of the research indicate that AfL could assess the class activities comprehensively. It could assess teacher and students' behavior in the class. The teacher guides the class from preparing the class, delivering materials and evaluating the class. Meanwhile students' behavior in the classes of pragmatics is better then in vocabulary. Students who express positive behavior in the classes of vocabulary are in the range of $30 \%$ $60 \%$ and around $80-90 \mathrm{~s} \%$ in pragmatics.
\end{abstract}

Keywords: Assessment for Learning, Evaluation, Vocabulary, Pragmatics, English Teaching Learning

\begin{abstract}
Abstrak
Tujuan penelitian ini adalah untuk melihat kehandalan penerapan Assessment for Learning (AFL) di kelas vocabulary dan pragmatik. Subyek penelitian ini adalah mahasiswa dan dosen di kelas Vocabulary 3
\end{abstract}


dan Pragmatics di Sekolah Tinggi Agama Islam Negeri (STAIN) Salatiga, Jawa Tengah, Indonesia. Hasil penelitian menunjukkan bahwa AfL dapat menilai aktivitas kelas secara menyeluruh. AFL dapat menilai perilaku pengajar dan mahasiswa di kelas. Pengajar memandu kelas mulai dari persiapan, penyampaian materi, dan evaluasi.Sementara itu, perilaku mahasiswa di kelas pragmatik lebih baik daripada kelas vocabulary. Mahasiswa yang menunjukkan perilaku positif di kelas vocabulary berada pada kisaran 30\% - 60\% dan sekitar $80-90$ an $\%$ di kelas pragmatics.

Keywords: Assessment for Learning, Evaluasi, Vocabulary, Pragmatik, Pembelajaran Bahasa Inggris

\section{Introduction}

Evaluation is one of a series of activities to enhance the quality, performance or productivity of an organization in carrying out a program. The purpose of evaluation is to see and know the processes that occur in the learning process. Through evaluation, information about what has been accomplished and what is not will be obtained (Djemari Mardapi, 2008: 19). There are three terms that are often used in the evaluation: measurement, assessment and evaluation. According to Griffin \& Nix (1991) measurements, assessment and evaluation are hierarchical. The criteria of measurement to compare observations, assessment describes and interprets the results of measurement, while the evaluation is the determination of the value or behavioral implications. Quality of learning can be seen from the results of the assessment. Atkin, Black, \& Cofey (2001) distinguished a judgment based on the goal of formative assessment and summative assessment. 
In general, the formative assessment has not been done properly because there are three factors. The first is the method of assessment. Teacher-made tests like the one in the faculty handbook, and replicate tests contained in the collection is still a matter of choice used. The forms of such tests have not been designed as part of the learning process yet. The second factor, the use of data assessment has not been carried out. The ability of teachers to use assessment results for the purpose of improving the quality of learning is still low. Assessment data is only used by faculty to determine grades (level or achievement) and students' feedback is rarely given. The third factor is a student, as a result of learning and formative assessment performed by lecturers, as noted above, students become lazy to learn and practice. The results of presurvey by using questionnaires and informal interviews were conducted on teaching English in Makassar and Yogyakarta (DIY) indicate: (1) that the general teaching (teacher/lecturer) understand formative assessment as the assessment of the results of tests given each end of subject and done 4-5 times in a semester, (2) a test that is used for the description and assessment of the multiple-choice test that is made, taken from handbook or collection matter, (3) feedback on assignments and exams are rarely given, (4) teaching (teacher/lecturer) rarely involve learners in their selfassessment process, (5) remedial (Mansur: 2009: 10).

AFL is the assessment that occurs in the classroom and involves students in every aspect of the assessment to build their confidence and maximize achievement. This assessment was suitable for all situations and provides benefits, for faculty and students in identifying next learning steps necessary to make progress, strengths and weaknesses are 
owned by faculty and students (CEA, 2003; Assessment Reform Group, 1999). The AFL draft has to provide insight into the learning benefits to students and teachers (Stiggins, 2002: 9). Benefits derived by lecturers, namely (1) they will become confident learners because they were able to see themselves and (2) they are able to understand what the meaning of the responsibility for their own learning to monitor greater success in the future. Benefits for students are: (1) students are motivated to learn, (2) faculty instructional decisions about student learning progress can be delivered with accurate information.

The rapid global communication and interaction put English as one of the media is absolutely necessary. Without adequate English proficiency, STAIN Salatiga graduates will face many problems in establishing global interaction. Crystal (2000: 1) states "English is a global language." This statement has a meaning that English is a global language, used by different nations to communicate with other nations around the world. English is a tool to communicate orally and in writing. Understanding is intended to communicate is to deliver, accept, understand, and express information, thoughts, feelings and develop science, technology, and culture in the English language. Ability to communicate in a full understanding is the ability of discourse (Departemen Pendidikan Nasional, 2003: 13).

Similarly, in the context of education, the English language serves as a tool to communicate in order to access information, and in the context of everyday life, as a means to foster relationships, share information and enjoy the aesthetics of language in English culture. Given the importance of mastering English, hopefully English could be 
mastered by STAIN Salatiga students. Therefore, teachers need to devise innovative methods of learning English in order to explore, understand, explain, or describe learning English as well as explore innovative methods tested in overcoming learning English. One of the innovative methods that can be done to address the problem of learning English using the model above is Assessment for Learning (AFL). AFL is a model of assessment that can clearly reveal student mastery of the English concept step by step.

\section{Assessment for Learning}

Model Assessment for Learning(AFL) was developed through a combination of assessment and classroom practice. The principles underlying the birth of the AFL conclusions drawn from the results review formative assessment conducted by Blackand William (Assessment Reform Group, 1999:4-5), namely:

"(a) the active involvement of children in their own learning, (b) the provision of effective feedback to children, (c) a recognition of the profound influence assessment has on motivation and self-esteem of children, both of roommates are crucial influence of learning, (d) the need of children to assess and themselves understand how to improve; and (e) adjusting teaching to take account of the result of assessment."

Based on the conclusions drawn by William Black, the underlying principle of the AFL include active student involvement in learning, improve the effectiveness of feedback, the use of assessment results to motivate and sensitize studentsto want tolearn so that they overshadow success. Lecturer gives the students the opportunity to assess themselves 
and adjust teaching strategies to get the results. AFL gives emphasis on the process undertaken by the faculty to seek information related to the problems faced by students. To obtain such information, it requires assessment instrument sthat can clearly reveal the problems and needs faced by students as shown below:

Low self-esteem

High self-esteem

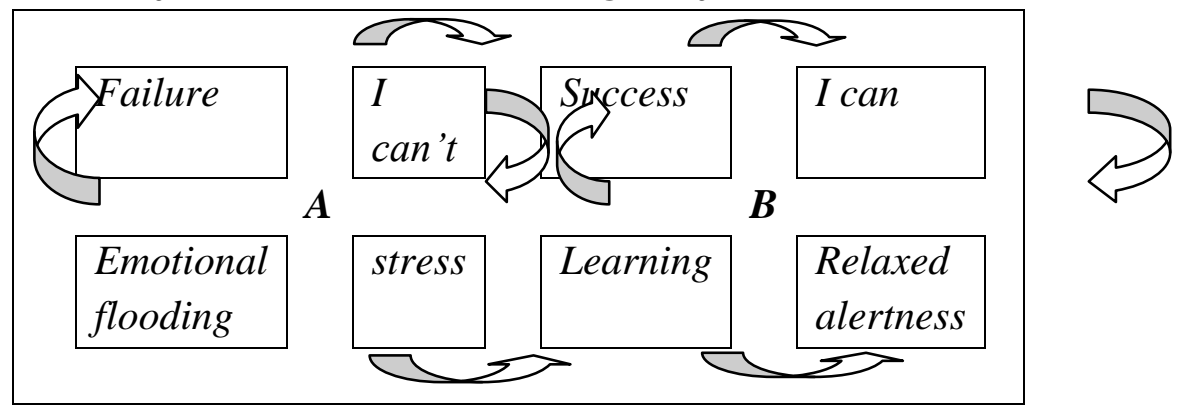

In this regard, lecturer suggests AFL cycle of self-esteem. Students are able to learn, face new challenges in a state of preparedness, a statement of the maximum to take risks and learn.AFL goal by CEA (2003: 2) are: a) give insight into student learning to faculty and students, b) increase success for all, c) assist in the establishment of learning goals, d) allowing continuous reflection on what students know today and what they need to know next, e) measure what is valued, and f) improve the standards obtained by the students on adages of capability.

The principle of the AFL is an effective part of the learning plan. A plan needs to provide opportunities for teachers and learners to acquire and use information on the progress of learning objectives. In addition, the plan must be flexible to respond to the emerging skills and ideas. Planning should include strategies to ensure that learners understand the goals they want to achieve and the criteria that will be used to assess their 
work. How students receive feedback, how they can take part in assessing their learning and how they will help to make further progress should also be planned.

Based on the study of theory, the results of pre-surveys conducted and the results of the preliminary study, the model "Assessment For Learning (AFL)" developed in this study consists of several components, namely: 1). Observation consists of observations of students and faculty behavior: at the beginning and during the teaching learning proses. Observations made by a lecturer in English that is used exclusively during the learning process. 2). Task Two phase (T-D-T). In phase-1 (stage-1), the teacher gave the package to students about 10-20 minutes to complete. The results of the work carried out as a stag-1 basis in providing the questions on the stage-2 (stag-2) to be completed at home. 3). Self-assessment given to students to assess themselves during the learning process by using the strategy of traffic light (TL).4). Feedback. Besides developing the instruments above, the assessment criteria and scoring rubric were also developed. Component model described above can be seen in the following figure:

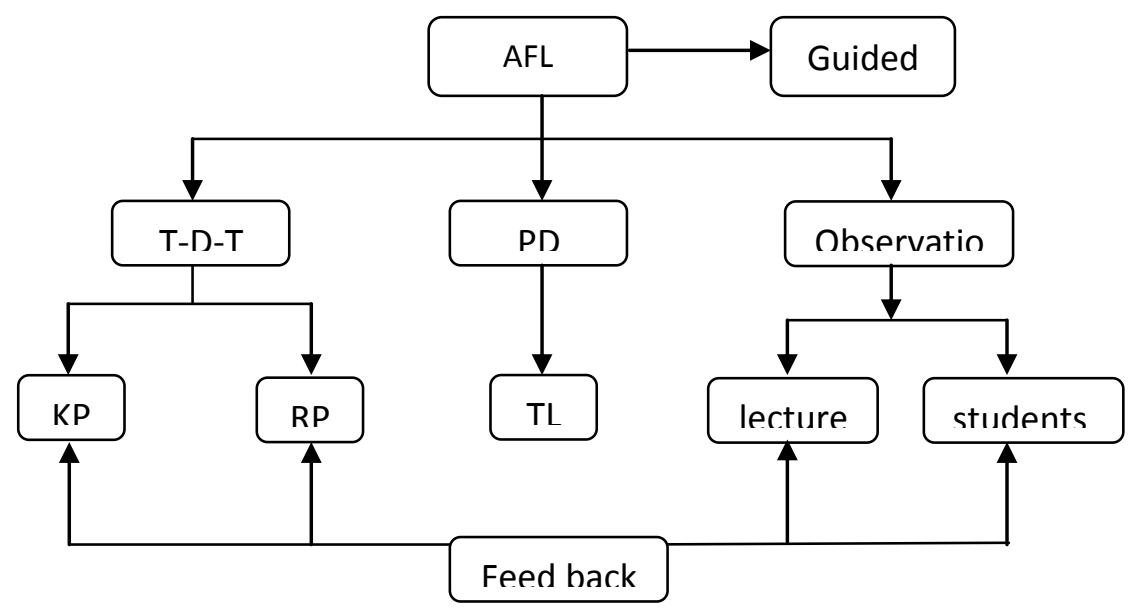




\section{Research method}

The subjects of the research were students and lecturers of Vocabulary 3 and Pragmatics classes. The research was conducted in State Institute of Islamic Studies (STAIN) Salatiga, Central Java, Indonesia. The classes of Pragmatics were selected because of the variety of background knowledge that could explore students' language competence in different contexts and cultures. Meanwhile, selecting of Vocabulary classes was based on facts that there are many new foreign words.

The research had quantitative and qualitative data. Quantitative data were collected from test, closed students' self assessment, and observation. Meanwhile, qualitative data were open students' self assessment. The instruments to collect data were observation sheets to observe behavior and students' scoring sheet. The research applied repeated measures analysis and principal component analysis (Mansur, 2009: 433)

\section{Discussion}

Assessment for Learning (AFL) is an assessment model used to assess students' progress so that teachers can modify learning to the real needs of students. The following data are about teacher's behavior, students' behavior and applicability of AFL.

\section{Teacher's behavior}

The assessment of teacher's behavior informs the teacher's activities in delivering material in the classroom. 


\section{Table 1}

\section{Teacher's behavior in the classroom}

\begin{tabular}{|c|l|c|c|}
\hline No & \multicolumn{1}{|c|}{ Indicators } & yes & no \\
\hline 1 & Teacher opened the class & $\mathrm{V}$ & \\
\hline 2 & Teacher and students shared the basic competence to obtain & $\mathrm{V}$ & \\
\hline 3 & Teacher and students shared grading criteria & $\mathrm{V}$ & \\
\hline 4 & Teacher and students shared achievement indicators & $\mathrm{V}$ & \\
\hline 5 & Teacher and students motivated each other & $\mathrm{V}$ & \\
\hline 6 & Teacher delivered materials and their examples & $\mathrm{V}$ & \\
\hline 7 & Teacher observed the students behavior in class & $\mathrm{V}$ & \\
\hline 8 & Teacher gave assignment 1 & $\mathrm{V}$ & \\
\hline 9 & Students did the assignment & & \\
\hline 10 & Teacher observed the students behavior in doing the & $\mathrm{V}$ & \\
\hline 11 & Teacher gave self assessment sheets & $\mathrm{V}$ & \\
\hline 12 & Students completed the self assessment & $\mathrm{v}$ & \\
\hline 13 & Teacher checked the students' work of the assignment 1 & $\mathrm{V}$ & \\
\hline 14 & Teacher gave written feedback for the assignment 1 & $\mathrm{V}$ & \\
\hline 15 & Teacher returned the result of the assignment 1 to students & & \\
\hline 16 & Teacher gave classical feedback of the assignment 1 & & \\
\hline 17 & Teacher gave assignment 2 as homework & V & \\
\hline 18 & Teacher closed the class & & \\
\hline
\end{tabular}


Applicability of Model Assessment for Learning (AFL) in Classes of Vocabulary and Pragmatics in English Teaching Learning at STAIN Salatiga

\section{Students' behavior}

The following data are the assessment of students' behavior in classes of vocabulary (V) andpragmatic (P).

Table 2

Students' behavior

\begin{tabular}{|c|c|c|c|c|}
\hline No & \multicolumn{2}{|c|}{ Indicator } & $\mathrm{V}$ & $\mathrm{P}$ \\
\hline \multirow[t]{6}{*}{1} & \multicolumn{4}{|c|}{ Students Listened intently to the teacher's explanation } \\
\hline & A & Looking forward to the board or to the teacher & $30 \%$ & $80 \%$ \\
\hline & $\mathrm{B}$ & Drowsy & $33 \%$ & $0 \%$ \\
\hline & $\mathrm{C}$ & Shaking & $30 \%$ & $1 \%$ \\
\hline & $\mathrm{D}$ & Frowning & $45 \%$ & $1.2 \%$ \\
\hline & $\mathrm{E}$ & Smile & $55 \%$ & $99 \%$ \\
\hline \multirow[t]{4}{*}{2} & \multicolumn{4}{|c|}{ Students took note ofthe important information from teacher's description } \\
\hline & A & $\begin{array}{l}\text { Taking note of what is written or drawn on the } \\
\text { board teacher }\end{array}$ & $30 \%$ & $80 \%$ \\
\hline & B & $\begin{array}{l}\text { Recording oral explanation of teachers that are not } \\
\text { written on the board }\end{array}$ & $30 \%$ & $80 \%$ \\
\hline & $\mathrm{C}$ & Taking note of the answers given to the student & $30 \%$ & $80 \%$ \\
\hline \multirow[t]{4}{*}{3} & \multicolumn{4}{|c|}{ Students' question } \\
\hline & A & It is informative & $30 \%$ & $90 \%$ \\
\hline & B & It is analytic & $30 \%$ & $90 \%$ \\
\hline & $\mathrm{C}$ & It is significant questions & $60 \%$ & $80 \%$ \\
\hline \multirow[t]{3}{*}{4} & \multicolumn{4}{|c|}{ Students' opinion } \\
\hline & $\mathrm{A}$ & $\begin{array}{l}\text { Delivering information that relate to class } \\
\text { materials }\end{array}$ & $30 \%$ & $80 \%$ \\
\hline & $\mathrm{B}$ & Giving proposals & $23 \%$ & $87 \%$ \\
\hline \multirow[t]{2}{*}{5} & \multicolumn{4}{|c|}{ Students' behavior } \\
\hline & $\bar{A}$ & Sitting calmly & $78 \%$ & $98 \%$ \\
\hline
\end{tabular}




\begin{tabular}{|l|l|l|c|c|}
\hline & B & Not interfering classmates & $30 \%$ & $86 \%$ \\
\cline { 2 - 5 } & C & Doing assignment quietly & $30 \%$ & $84 \%$ \\
\hline
\end{tabular}

\section{Affectivity of AFL}

Effectiveness Model Assessment for Learning is classified into 1 (poor), 2 (less effective), 3 (good), 4 (very good) in classes of Vocabulary (V) and Pragmatics (P). They are (a)instrument model can be used to assess the attitudes, experiences, skills and attitudes in the English language learning or validity, V: 1 and P: 4; (b) instrument model if use dto assess the attitudes, experience, language skills and behaviorin learning will repeatedly give the same resultsor reliability, V: 1 and $\mathrm{P}: 4$; (c) this model canbe used to obtain information as it is about the attitudes, experiences, skills and attitudes in learning English or Objective, V: 4 and P: 4; (d) this model is used in a systematic and continuous learning in every classroom or systematic, V: 4 and P: 4; (e) this model ispractically used to collect information relating to the implementation of learningand teaching classroomor practicality, V: 2 or P: 4.

\section{Applicability of AFL}

Based on the data above, model assessment for learning is applicable for the class of Vocabulary and Pragmatics and can be used to observe classes comprehensively. It can be used to observe teacher and students activities. As the above data, the teacher prepared the class, delivered materials, and evaluated the class. Meanwhile, the students' behavior in the classes informs their attitudes toward class and it 
indicates the problems and strengths of the class as well as students record.

\section{Conclusion}

The information displayed when using model-AFL in learning is accurate and in accordance with the real needs of students in terms of student understanding of the learning materials, student behavior during learning, and English language skills of students. AFL can be used through feedback and reflection. Student learning abilities are displayed by individual profiles and class profiles. Both of these profiles show an understanding of the development trend of the individual (or class) of the learning materials, student behavior during learning, and the students' English language abilities for each meeting.

AFL model has several advantages, namely: this model can display the individual profiles in the form of student understanding, behavior, and self-assessment. This model can be used to diagnose learning difficulties or misconceptions on students on subjects that can give help and guidance, obtaining adequate information and according to the real problems faced by students and faculty, establishing good communication between faculty and students through student selfassessment applied, building awareness and responsibility in a professional faculty with a reflection on the results achieved at each meeting, raising awareness, responsibility, motivation, confidence, and independence of students in learning, providing a sense of justice to students through feedback, encouraging faculty and students to continue to make improvements and increase the quality of teaching and learning 
continuously, fostering mutual trust between faculty and students in the assessment, avoid subjectivity lecturer in providing assessment decisions for students and increasing accountability for public universities.

\section{References}

Atkin, J.M., Black, P., \& Cofey, J. 2001. Classroom Assessment and the National Science Education Standards. New York: National Academy Press.

Assesment Reform Group. 1999. Assessment for Learning: Beyond The Black Box. University of Cambridge School Of Education. Retrieved 1 December 2010 from http://www.Assesment-reformgroup.org.uk.

CEA. 2003. Quality Statement on Assessment Practice (Second). Retrieved 5 Desember 2010 from http://www.aaia.org.uk

Crystal, D. 2000. English As A Global Language. Cambridge: Cambridge University Press.

Departemen Pendidikan Nasional.2003. Kurikulum 2004, Stándar Kompetensi, Mata Pelajaran: Bahasa Inggris Sekolah Menengah Atas.Jakarta: Pusat Kurikulum, Balitbang Depdiknas.

Djemari, M. 2008. Teknik Penyusunan Instrumen Tes dan Nontes.Yogyakarta: Mitra Cendikia Press.

Griffin, Patrix and Nix, P. 1991. Educational Assessment and Reporting.Sidney: Harcout Brace Javanovich Publisher.

Mansur. 2009. Pembelajaran Bahasa Inggris. Yogyakart: UNY Press

Stiggins, R.J. 2002.Assessment Eurasia: The Absence of Assessment for Learning.India: Phi Delta Kappan. 
Applicability of Model Assessment for Learning (AFL) in Classes of Vocabulary and Pragmatics in English Teaching Learning at STAIN Salatiga 